BIOMA 11 (1), 2015

Biologi UNJ Press

ISSN : 0126-3552

\title{
DETERMINASI PEMBERIAN MINYAK TRANS TERHADAP STRES OKSIDATIF PADA TIKUS GALUR WISTAR DENGAN MALONDIALDEHIDA PANKREAS SEBAGAI INDIKATOR
}

\author{
MAWALI MAHARJA ${ }^{1}$, SANTOSO K, KUSUMORINI N ${ }^{1}$, SATYANINGTIJAS AS ${ }^{1}$ \& \\ ATIN SUPIYANI² \\ ${ }^{1}$ Jurusan Biologi FMIPA Universitas Negeri Jakarta (UNJ). Jl. Pemuda No. 10 Rawamangun, Jakarta Timur. 13220. \\ Indonesia. \\ ${ }^{2}$ Institut Pertanian Bogor, Bogor, Indonesia \\ *Email: atinsupiyani78@gmail.com \\ Tanggal publikasi online:
}

\begin{abstract}
Trans fatty acids (TFAs) are the entire unsaturated fatty acids containing one or more double bonds isolated in trans configuration believed as predisposing factor of oxidative stress, excluding conjugated double bond fatty acids. Malondialdehyde (MDA) is a product of lipid peroxidation used as oxidative stress marker. The objective of this study was to see the correlation between TFAs containing-oil (consists of 3-6\% TFAs) intake at various administration doses and pancreatic MDA levels in Wistar rats. Twelve rats were grouped according to administration doses $(20 \%, 40 \%, 60 \%$ of given feed total energy and control group). TFAs containing-oil was administered orally once a day for 70 days at given doses by force feeding. Pancreatic MDA were measured using TBARS assay adapted from Singh et al. (2006). Increase of TFAs containing-oil administration dose caused insignificant increase of pancreatic MDA level.
\end{abstract}

Keywords: trans fatty acids, oxidative stress, malondialdehyde, Wistar rats, palm oil

\section{PENDAHULUAN}

Konsumsi makanan yang diolah dengan metode deep frying menggunakan minyak kelapa sawit merupakan hal yang tak dapat dipisahkan dari kehidupan masyarakat saat ini. Sartika (2008) menerangkan bahwa proses menggoreng dengan cara deep frying menyebabkan perubahan asam lemak tidak jenuh bentuk cis menjadi bentuk trans dan meningkatkan jumlah asam lemak trans sebanding dengan penurunan asam lemak tidak jenuh konfigurasi cis. Pemanasan menyebabkan minyak mengalami serangkaian reaksi kimia seperti oksidasi, hidrolisis, dan polimerisasi (Choe dan Min 2007). Kavita dan Malika (2013) menyatakan bahwa lemak trans bersifat seperti lemak jenuh dengan meningkatkan kadar low density lipoprotein (LDL), tetapi lain halnya dengan lemak jenuh, lemak trans memiliki efek menurunkan kadar high density lipoprotein (HDL).

Lemak trans dipercaya sebagai salah satu sumber dari stres oksidatif (Martin et al. 2007); 
yakni suatu kondisi dimana terjadi kelebihan reactive oxygen species (ROS) yang merupakan radikal bebas akibat tidak seimbangnya laju produksi dengan laju pembuangan ROS karena berlebihnya produksi ROS, berkurangnya antioksidan yang dapat menurunkan ROS, maupun keduanya (McMichael 2007) dengan peningkatan konsentrasi asam lemak bebas plasma sebagai faktor predisposisi (de Marchi et al. 2013). Produksi radikal bebas yang relatif berlebihan dapat menyerang berbagai komponen seluler, termasuk diantaranya lipid, protein dan DNA (Jiqu et al. 2011). Stres oksidatif sangat berkorelasi dengan berbagai penyakit metabolik dan kondisi inflamasi (Noeman et al. 2011) seperti pankreatitis akut (Andican et al. 2005) maupun kronis; diduga bahwa stres oksidatif berdampak pada kerusakan sel-sel asinar sehingga memicu otodigesti terhadap pankreas (Verlaan et al. 2006) yang berlanjut pada nekrosis sel beta pankreas (Tjahjono et al. 2013). Selain itu, kandungan antioksidan alami pada minyak kelapa sawit mengalami penurunan setelah proses penggorengan pada suhu tinggi (Ali et al. 2012).

Peroksidasi lipid merupakan suatu proses kompleks yang berujung pada pembentukan berbagai macam aldehida, termasuk diantaranya malondialdehida (MDA) (Agarwal dan Prabakaran 2005) yang digunakan sebagai penanda stres oksidatif (Chou et al. 2008). MDA dapat diukur melalui beberapa jenis pengujian, namun metode yang paling sederhana dan yang paling umum digunakan yakni thiobarbituric acid reactive substances assay (TBARS) (Lee et al. 2012) sehingga digunakan pada penelitian ini. Walaupun konsentrasi komponen-komponen antioksidan plasma dapat diukur, pengukuran tersebut memakan waktu dan biaya yang besar dan memerlukan banyak tenaga kerja (Suresh et al. 2010).

Gaya hidup yang mengarah pada konsumsi makanan yang mengandung asam lemak trans terutama yang diolah dengan metode deep frying menyebabkan pentingnya untuk melihat hubungan antara tingkat konsumsi minyak trans dengan stres oksidatif pada pankreas tikus galur Wistar sebagai hewan model. Penelitian ini bertujuan untuk melihat pengaruh pemberian minyak trans dengan berbagai dosis dalam menimbulkan perubahan bobot pankreas serta stres oksidatif pada tikus galur Wistar dengan MDA pankreas sebagai indikatornya. Hasil penelitian diharapkan dapat memberikan informasi kepada masyarakat mengenai tingkat stres oksidatif pada pankreas akibat pemberian minyak trans sebagai pakan tambahan pada hewan coba tikus galur Wistar. Selain itu, mengingat manfaat tikus Wistar sebagai hewan model, penelitian ini diharapkan dapat menjadi pustaka acuan bagi penelitian-penelitian terkait stres oksidatif pada manusia

\section{METODE}

\section{Alat dan Bahan}

Peralatan yang digunakan antara lain kandang pemeliharaan, alat pencekok kapasitas $5 \mathrm{~mL}$, alat bedah minor, timbangan dengan tingkat ketelitian $0.01 \mathrm{~g}$ (AND FG-3000), sentrifuge $3000 \mathrm{rpm}$ (Heraeus 400R) dan $10000 \mathrm{rpm}$ (Sorvall RC 5B Plus), tabung eppendorf, pemusar, spektrofotometer

(Hitachi U-2001), tabung kuvet, freezer (Sanyo HF-S4H), tabung reaksi, cawan porselen, serta oven.

Bahan yang digunakan untuk penelitian ini adalah 12 ekor tikus galur Wistar, pellet standar tikus berupa pellet dari PT. Comfeed Indonesia, minyak kelapa sawit sebagai pakan tambahan, 
larutan phosphate buffered saline kalium klorida (PBS-KCl) dengan nilai pH PBS 7.4 serta konsentrasi $\mathrm{KCl}$ sebesar $11.4 \mathrm{~g} / \mathrm{L}$, asam tiobarbiturat (TBA), asam trikoloroasetat (TCA), asam klorida, larutan standar 1,1,3,3-tetraetoksipropana (TEP), serta batu es.

\section{Waktu dan Tempat Penelitian}

Penelitian dilaksanakan dari bulan Februari sampai Mei 2014 di Unit Pengelola Hewan Laboratorium (UPHL) dan Laboratorium Fisiologi, Fakultas Kedokteran Hewan, Institut Pertanian Bogor.

\section{Prosedur Penelitian}

Pemilihan Hewan Coba dan Pembagian Kelompok

Hewan yang digunakan dalam penelitian ini adalah tikus jantan dewasa galur Wistar berusia 12 minggu dengan bobot badan 200-250 g sebanyak 12 ekor. Tikus dipelihara dalam kandang plastik berukuran $30 \times 40 \mathrm{~cm}$ dengan tutup terbuat dari kawat ram dan dialasi serbuk kayu. Tikus diberi pakan pellet standar dan minum ad libitum. Lingkungan kandang dibuat tidak lembab dengan sirkulasi udara yang baik, serta pencahayaan yang cukup terang (kurang lebih 14 jam) dan gelap selama kurang lebih 10 jam.

Tikus dibagi menjadi empat kelompok yang terdiri dari kelompok kontrol sebanyak tiga ekor serta kelompok perlakuan minyak trans sebanyak 9 ekor yang kemudian dibagi lagi berdasarkan dosis minyak trans yang diberikan $(20 \%, 40 \%$, serta $60 \%$ energi total pakan yang diberikan), masing-masing tiga tikus pada setiap dosis perlakuan.

\section{Pembuatan dan Pemberian Minyak Trans serta Pemberian Pakan}

Minyak trans dibuat dengan merujuk pada Tuminah (2009). Minyak kelapa sawit dipanaskan pada suhu $280{ }^{\circ} \mathrm{C}$ selama 10 menit. Dalam kondisi tersebut, diharapkan terjadi pembentukan 3-6\% asam lemak trans.

Minyak trans diberikan setiap hari melalui pencekokan selama 70 hari dengan dosis pemberian $20 \%$ energi total pakan pada kelompok pertama, $40 \%$ energi total pakan pada kelompok kedua, serta $60 \%$ energi total pakan pada kelompok ketiga. Energi total pakan ditentukan setelah dilakukannya observasi terhadap pola konsumsi pakan tikus pada periode pra penelitian. Setelah dilakukan observasi, didapat bahwa pola konsumsi pakan adalah $15.6 \mathrm{~g} / \mathrm{ekor} / \mathrm{hari}$. Setelah dikalikan dengan nilai energi pakan (4 kkal/g), didapat bahwa energi total pakan harian adalah $62.4 \mathrm{kkal} / \mathrm{ekor} / \mathrm{hari}$. Tikus-tikus kontrol hanya diberikan pakan standar sebagai asupan harian.

\section{Koleksi dan Penimbangan Pankreas}

Laparotomi dilakukan untuk pengambilan organ pankreas. Sebelum pembedahan, dilakukan pembiusan dengan eter secara perinhalasi yang dilanjutkan dengan dislokasi servikal. Pankreas ditimbang kemudian disimpan dalam freezer.

\section{Persiapan Sampel}

Metode preparasi dan pengukuran sampel diadaptasi dari Singh et al. (2006). Sebanyak 0.3 g sampel pankreas dicincang halus dalam kondisi dingin, ditambahkan $0.6 \mathrm{~mL}$ larutan $\mathrm{PBS}-\mathrm{KCl}$, kemudian disentrifugasi dengan kecepatan $10000 \mathrm{rpm}$ selama 20 menit pada suhu $4{ }^{\circ} \mathrm{C}$. Supernatan 
diambil sebanyak $500 \mu \mathrm{L}$; ditambahkan $2 \mathrm{~mL}$ larutan campuran yang dibuat dari $0.7 \mathrm{~mL} \mathrm{HCl}$ pekat, $4.5 \mathrm{~g}$ TCA, serta $0.114 \mathrm{~g}$ TBA; lalu ditambahkan aquades ad $30 \mathrm{~mL}$. Campuran tersebut dipusar, dioven pada suhu $80{ }^{\circ} \mathrm{C}$ selama satu jam, kemudian disentrifusa dengan kecepatan 3000 rpm selama lima menit setelah didinginkan hingga tercapai suhu ruang.

\section{Pembuatan Larutan Standar}

Untuk pembuatan larutan kerja, sebanyak $10 \mu \mathrm{L}$ larutan TEP 4.4 M dilarutkan dengan $34 \mu \mathrm{L}$ air bebas ion. Sebanyak $10 \mu \mathrm{L}$ dari campuran tersebut diambil dan dilarutkan dengan $990 \mu \mathrm{L}$ air bebas ion. Sebanyak $100 \mu \mathrm{L}$ dari hasil pencampuran kedua diambil dan dicampurkan dengan 900 $\mu \mathrm{L}$ air bebas ion. Sebanyak $500 \mu \mathrm{L}$ dari pencampuran ketiga diambil dan dicampurkan dengan 500 $\mu \mathrm{L}$ air bebas ion. Konsentrasi akhir larutan kerja yang dicapai yakni $500 \mu \mathrm{M}$.

Larutan standar MDA yang digunakan terdiri atas tujuh larutan; dibuat dari larutan kerja masing-masing sebanyak $2.5 \mu \mathrm{L}, 5 \mu \mathrm{L}, 10 \mu \mathrm{L}, 20 \mu \mathrm{L}, 40 \mu \mathrm{L}, 50 \mu \mathrm{L}$, serta $100 \mu \mathrm{L}$ yang dilarutkan dengan aquades ad $250 \mu \mathrm{L}$. Dengan demikian, konsentrasi akhir masing-masing larutan standar secara berurutan yakni $5 \mu \mathrm{M}, 10 \mu \mathrm{M}, 20 \mu \mathrm{M}, 40 \mu \mathrm{M}, 80 \mu \mathrm{M}, 100 \mu \mathrm{M}$, serta $200 \mu \mathrm{M}$. Larutan standar dioven pada suhu $80{ }^{\circ} \mathrm{C}$ selama satu jam. Setelah didinginkan, larutan standar disentrifusa pada kecepatan 3000 rpm selama lima menit.

\section{Pengukuran Konsentrasi MDA dan Analisis Data}

Supernatan dan larutan standar dianalisa nilai absorbansinya dengan spektrofotometer pada panjang gelombang $532 \mathrm{~nm}$. Nilai absorbansi dan konsentrasi larutan standar diplotkan ke dalam grafik regresi linier, kemudian persamaan regresi yang diperoleh digunakan dalam penentuan nilai konsentrasi MDA pankreas. Konsentrasi MDA pankreas yang diperoleh dikonversikan satuannya dari mikromolar menjadi mikrogram MDA per gram sampel. Pengujian statistika yang dilakukan terhadap nilai konsentrasi MDA yakni one-way analysis of variance (ANOVA) yang kemudian akan dilanjutkan ke uji Duncan bila diperoleh hasil berpengaruh nyata serta uji korelasi. Piranti lunak SPSS Statistics 17.0 digunakan untuk pembuatan grafik regresi linier larutan standar, oneway ANOVA, serta uji korelasi.

\section{HASIL DAN PEMBAHASAN}

Rerata bobot pankreas tikus yang diobservasi yakni $0.30 \mathrm{~g}$ pada kelompok kontrol, $0.38 \mathrm{~g}$ pada kelompok dosis pemberian lemak trans 20\%, 0.32 g pada kelompok dosis pemberian 40\%, serta 0.30 g pada kelompok dosis pemberian $60 \%$. Rerata bobot pankreas tikus yang dicatat tidak berbeda nyata antar dosis pemberian minyak trans (sig. $>0.05$ ), dimana dosis pemberian minyak trans tidak berkorelasi dengan bobot pankreas $(\mathrm{R}=0.095)$. Norton et al. (1998) melaporkan bahwa

Tabel 1 Bobot pankreas tikus Wistar pada berbagai variasi dosis pemberian minyak trans

\begin{tabular}{ll}
\hline Dosis minyak trans & Bobot Pankreas $(\mathrm{g})$ \\
\hline Kontrol & $0.30 \pm 0.066$ \\
$20 \%$ energi total pakan & $0.38 \pm 0.050$ \\
$40 \%$ energi total pakan & $0.32 \pm 0.121$ \\
$60 \%$ energi total pakan & $0.30 \pm 0.043$ \\
\hline
\end{tabular}


tidak ada perbedaan bobot pankreas yang nyata antara tikus yang dibuat stres oksidatif oleh induksi menggunakan etanol dengan tikus kontrol.

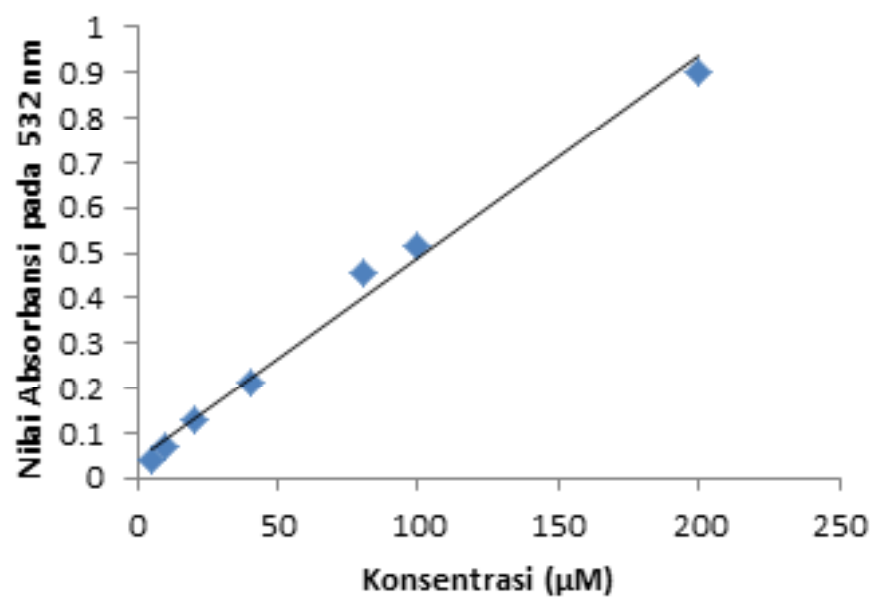

Gambar 2. Grafik regresi linier $y=0.043+0.004 x$ dari larutan standar MDA

Tabel 2 Konsentrasi MDA pankreas tikus Wistar pada berbagai variasi dosis pemberian minyak trans

\begin{tabular}{ll}
\hline Dosis minyak trans & Konsentrasi MDA pankreas $(\mu \mathrm{g} / \mathrm{g})$ \\
\hline Kontrol & $6.30 \pm 1.736$ \\
$20 \%$ energi total pakan & $7.65 \pm 2.099$ \\
$40 \%$ energi total pakan & $9.13 \pm 2.237$ \\
$60 \%$ energi total pakan & $9.46 \pm 0.760$ \\
\hline
\end{tabular}

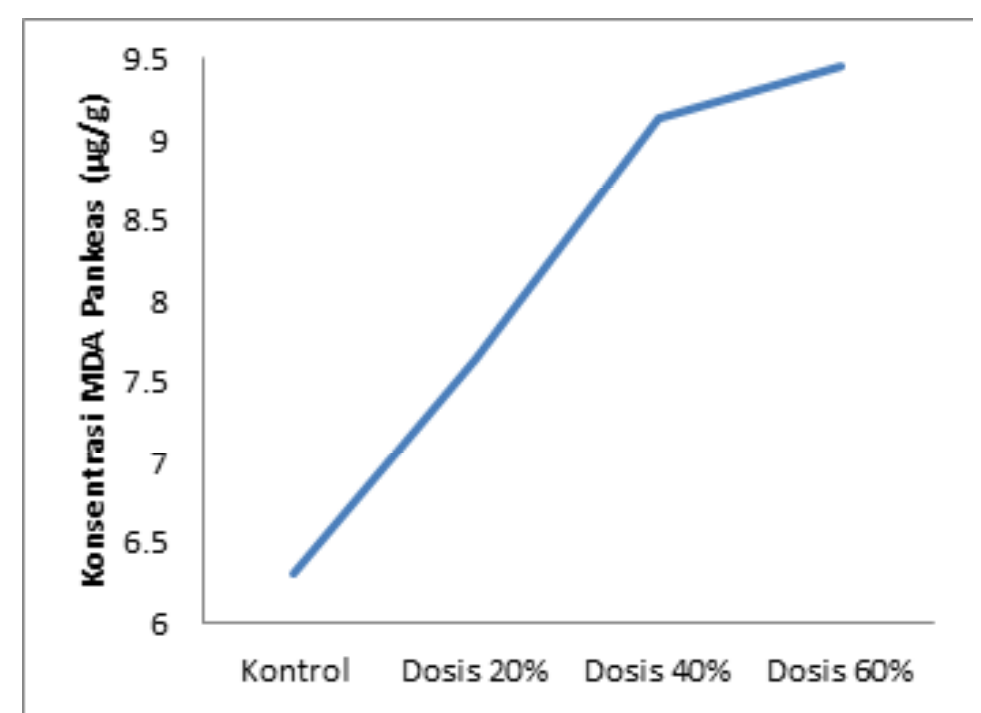

Gambar 3 Grafik konsentrasi MDA pankreas terhadap dosis minyak trans

Persamaan regresi linier (Gambar 2) yang diperoleh dengan memplotkan nilai absorbansi dan konsentrasi setiap larutan standar yakni $y=0.043+0.004 x(R 2=0.995)$ yang bermakna terjadi kenaikan nilai absorbansi senilai 0.004 setiap kenaikan konsentrasi larutan standar sebesar $1 \mu \mathrm{M}$. 
Rerata konsentrasi MDA pankreas yang diobservasi yakni $6.30 \mu \mathrm{g} / \mathrm{g}$ pada kelompok kontrol, $7.65 \mu \mathrm{g} / \mathrm{g}$ pada kelompok dosis $20 \%, 9.13 \mu \mathrm{g} / \mathrm{g}$ pada kelompok dosis $40 \%$, serta $9.46 \mu \mathrm{g} / \mathrm{g}$ pada kelompok dosis 60\%. Konsentrasi MDA yang dicatat tidak berbeda nyata antar kelompok (sig. > 0.05). Meski demikian, terdapat peningkatan konsentrasi MDA pankreas seiring peningkatan dosis pemberian minyak trans.

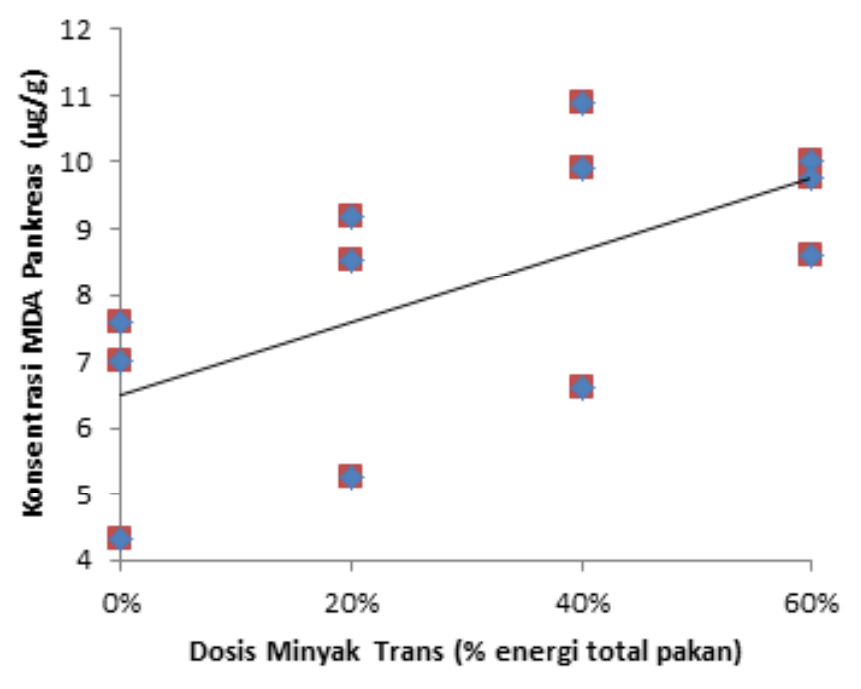

Gambar 4. Sebaran kurva uji regresi antara dosis pemberian minyak trans dengan konsentrasi MDA pankreas $(\mathrm{y}=$ $0.055 x+6.491)$

Hasil uji regresi pertambahan dosis pemberian minyak trans terhadap konsentrasi MDA pankreas berupa persamaan $\mathrm{y}=0.055 \mathrm{x}+6.491$ yang bermakna terjadi kenaikan konsentrasi MDA sebesar $0.055 \mu \mathrm{g} / \mathrm{g}$ setiap kenaikan dosis pemberian minyak trans sebesar $1 \%$ energi total pakan yang diberikan. Terdapat hubungan positif yang kuat antara dosis pemberian minyak trans dan konsentrasi MDA pankreas $(\mathrm{R} 2=0.632)$ dengan 40.0\% kenaikan konsentrasi MDA pankreas dipengaruhi oleh kenaikan dosis pemberian minyak trans $(\mathrm{R} 2=0.400)$.

Kenaikan pada konsentrasi MDA terkait dengan penurunan konsentrasi superoxide dismutase (SOD) (Yan-Hong et al. 2006), yakni suatu antioksidan yang berperan sebagai penangkal oxygen free radicals (OFR) (Dziurkowska-Marek et al. 2004). SOD merubah radikal-radikal anion superoksida yang dihasilkan tubuh menjadi hidrogen peroksida, dengan demikian mengurangi kemungkinan anion superoksida berinteraksi dengan nitrit oksida membentuk peroksinitrit reaktif (Maritim et al. 2003).

Tingginya variasi rerata konsentrasi MDA pada setiap dosis dapat diakibatkan oleh teknik koleksi organ yang kurang memerhatikan kemurnian organ dimana terdapat kemungkinan terbawanya jaringan-jaringan ekstra pankreas seperti adiposa. Jaringan adiposa yang terpapar perlakuan asupan tinggi lemak secara kronis akan mengalami peningkatan stres retikulum endoplasma dan disfungsi mitokondria yang berdampak pada penurunan efisiensi konsumsi oksigen dan transpor elektron yang berujung pada terjadinya stres oksidatif (Frohnert dan Bernlohr 2014), sehingga apabila terbawa bersama pankreas saat analisis akan memengaruhi kemurnian data 
konsentrasi MDA pankreas. Campbell-Thompson et al. (2012) menerangkan bahwa koleksi organ pankreas dilakukan dengan terlebih dahulu menyingkirkan duodenum dan limpa yang dilanjutkan dengan pembersihan pankreas dari jaringan adiposa, pembuluh darah, serta syaraf ekstra pankreas menggunakan gunting tumpul-tajam.

Stres merupakan suatu kondisi terganggunya homeostasis yang bersumber dari luar maupun dalam seperti stimuli fisik maupun psikologik yang disebut sebagai stresor (Zafir dan Banu 2009). Stres kronis memengaruhi berbagai penyakit melalui berbagai reaksi biokimiawi yang berujung pada penuaan sel-sel imun. Respon terhadap stres yang terjadi secara langsung dapat menyebabkan inflamasi sistemik dan stres oksidatif (Epel 2009). Stres oksidatif berkaitan dengan heat stress pada ternak tropis melalui peningkatan peroksidasi lipid yang disertai penurunan tingkat antioksidan (Kumar et al. 2011) akibat kerusakan fungsi enzim-enzim antioksidan karena terjadinya peningkatan suhu tubuh (Heise et al. 2006). Pada anjing, stres oksidatif pernah dilaporkan berkaitan dengan babesiosis (Crnogaj et al. 2010) serta berbagai tipe kanker (Macotpet et al. 2013) dimana pada kelinci pernah dilaporkan terkait dengan asupan tinggi metionin (Yalçınkaya-Demirsöz et al. 2009) serta hipertiroidismus (Majeed dan Al-Azzawie 2012). Sedangkan pada unggas, stres oksidatif pernah dilaporkan terkait dengan defisiensi zink (Sahin et al. 2009), pemberian dexamethasone (Eid et al. 2008), serta pemberian enrofloxacin (Sureshkumar et al. 2013).

\section{SIMPULAN}

Pemberian asupan minyak trans pada tikus galur Wistar sebagai pakan tambahan tidak memengaruhi bobot pankreas tikus $(\mathrm{R}=0.095)$ serta tidak secara nyata memengaruhi konsentrasi MDA pankreas. Meski demikian, ada hubungan positif yang kuat antara peningkatan dosis pemberian minyak trans dengan konsentrasi MDA pankreas $(\mathrm{R}=0.632 ; \mathrm{y}=0.055 \mathrm{x}+6.491)$.

\section{DAFTAR PUSTAKA}

Agarwal A, Prabakaran SA. 2005 Mechanism, measurement, and prevention of oxidative stress in male reproductive physiology. Ind J Exp Biol [Internet]. [diunduh 2014 Sep 3]; 43:963974. Tersedia pada: http://ccf.org/reproductiveresearchcenter/docs/agradoc192.pdf.

Ali RAM, Sayed NHM, El-Monem DDA. 2012. Curcumin reduced potato chips and roasted bread induced chromosomal aberrations and micronuclei formation in albino rats. Life Scien $\mathrm{J}$ [Internet]. [diunduh 2014 Sep 1]; 9(1):474-480. Tersedia pada: http://www.lifesciencesite. com/lsj/life0901/047_7565blife0901_330_336.pdf.

Andican G, Gelisgen R, Unal E, Tortum OB, Dervisoglu S, Karahasasoglu T, Burcak G. 2005. Oxidative stress and nitric oxide in rats with alcohol-induced acute pancreatitis. World $\mathrm{J}$ Gastroenterol [Internet]. [diunduh 2014 Sep 3]; 11-2340-2345. Tersedia pada: http://www. ncbi.nlm.nih.gov/pubmed/15818750.

Andreollo NA, dos Santos EV, Araújo MR, Lopez LR. 2012. Rat's age versus human's age: what is the relationship?. ABCD Arq Bras Cir Dig. 25(1):1-3. doi: 10.1590/S010267202012000100011.

Angelova P, Boyadjiev N. 2013. A review on the models of obesity and metabolic syndrome in rats. 
Trakia J Scien [Internet]. [diunduh 2014 Sep 8]; 1:5-12. Tersedia pada: http://tru.uni-sz. bg/tsj/vol11N1_2013/P.Angelova.pdf.

Augustine SH. 1994. Nutritional aspects of palm oil: an introductory review. Asia Pasific J Clin Nutrit [Internet]. [diunduh 2014 Sep 28]; 3:201-206. Tersedia pada: http://apjen.nhri.org. tw/server/apjen/3/4/201.pdf.

Campbell-Thompson ML, Montgomery EL, Foss RM, Kolheffer KM, Phipps G, Schneider L, Atkinson MA. 2012. Collection protocol for human pancreas. J Visualiz Experimen. 63(e4039):1-5. doi:10.3791/4039.

Choe E, Min DB. 2007. Chemistry of deep-fat frying oils. J Food Scien. 72(5):77-86 dalam Jaarin K, Kamsiah Y. 2012. Repeatedly heated vegetable oils and lipid peroxidation. Intech. 10:211-228. doi:10.5772/46076.

Chou MY, Hartvigsen K, Hansen LF, Fogelstrand L, Shaw PX, Boulolier A, Binder CJ, Witztum JL. 2008. Oxidation-specific epitopes are important targets of innate immunity. J Intern Med. 263(5):479-88. doi:10.1111/j.1365-2796.2008.01968.x.

Crnogaj M, Petlevski R, Mrljak V, Kis I, Torti M, Kucer N, Matijatko, Sacer I, Stokovic I. 2010. Malondialdehyde levels in serum of dogs infected with Babesia canis. Veterinar Medic [Internet]. [diunduh 2014 Sep 21]; 55(4):163-171. Tersedia pada: http://vri.cz/docs/ vetmed/55-4-163.pdf.

De Marchi E, Baldassari F, Bononi A, Wieckowski MR, Pinton P. 2013. Oxidative stress in cardiovascular diseases and obesity: role of p66Shc and protein kinase c. Oxid Med Cel Long. 2013:1-11. doi:10.1155/2013/564961.

Dziurkowska-Marek A, Marek TA, Nowak A, Kacperek-Hartleb T, Sierka E, Nowakowska-Dulawa E. 2004. The dynamics of the oxidant-antioxidant balance in the early phase of human acute biliary pancreatitis. Pancreatology. 4:215-222. doi:10.1159/000078432.

Eid Y, Ebeid T, Moawad M, El-Habbak M. 2008. Vitamin e supplementation reduces dexamethasoneinduced oxidative stress in laying hens. Egypt Poult Scien [Internet]. [diunduh 2014 Sep 21]; 28(3):785-798. Tersedia pada: http://www.researchgate.net/publication/235355872_ VITAMIN_E_SUPPLEMENTATION_REDUCES_DEXAMETHASONEINDUCED_ OXIDATIVE_STRESS_IN_LAYING_HENS

Epel ES. 2009. Psychological and metabolic stress: a recipe for accelerated cellular aging?. Hormones [Internet]. [diunduh 2014 Sep 21]; 8(1):7-22. Tersedia pada: http://www. hormones.gr/pdf/Stress\%20and\%20cell\%20aging.pdf.

Frohnert BI, Bernlohr DA. 2014. Glutathionylated products of lipid peroxidation: a novel mechanism of adipocyte to macrophage signaling. Land Bioscien. 3(3):224-229. doi:10.4161/ adip. 28851.

Heise K, Puntarulo S, Nikinmaa M, Abele D, Pörtner H. 2006. Oxidative stress during stressful heat exposure and recovery in the north sea eelpout Zoarces viviparous L. J Experiment Biol. 209:353-363. doi:10.1242/jeb.01977.

Jiqu X, Xiaoqi Z, Qianchun D, Qingde H, Jin'e Y, Fenghong H. 2011. Rapeseed oil fortified with micronutrients reduces atherosclerosis risk factors in rats fed a high-fat diet. Lip Heal Dis [Internet]. [diunduh 2014 Aug 16]; 10(96):1-8. Tersedia pada: http://www.lipidworld. 
com/content/10/1/96.

Kavita MB, Malika K. 2013. Lifestyle interventions to promote health in dyslipidemics. Bul Pharmaceut Med Scien [Internet]. [diunduh 2014 Mar 23]; 1(2):108-114. Tersedia pada: http://www.bopams.com/Vol.1.\%20Issue\%202.2013/108-114.pdf.

Kumar S, Ajeet K, Meena K. 2011. Effect of heat stress in tropical livestock and different strategies for its amelioration. J Stress Physiol Biochem [Internet]. [diunduh 2014 Sep 21]; 7(1):4554. Tersedia pada: http://www.ansci.wisc.edu/jjp1/pig_case/html/library/Effect\%20of\%20 heat $\% 20$ stress $\% 20$ in $\% 20$ tropical\%20livestock.pdf.

Lee R, Margaritis M, Channon KM, Antoniades C. 2012. Evaluating oxidative stress in human cardiovascular disease: methodological aspects and considerations. Curr Med Chem. 19(16):2504-2520. doi:10.2174/092986712800493057.

Macotpet A, Suksawat F, Sukon P, Pimpakdee K, Pattarapanwichien E, Tangrassameeprasert R, Boonsiri P. 2013. Oxidative stress in cancer-bearing dogs assesed by measuring serum malondialdehyde. BMC Vet Res [Internet]. [diunduh 2014 Sep 2]; 9(101):1-6. Tersedia pada: http://www.biomedcentral.com/1746-6148/9/101.

Majeed MS, Al-Azzawie HF. 2012. Effect of ethanolic red cabbage extract on oxidative stress in hyperthyroid rabbits induced by L-thyroxine. Iraqi J Scien [Internet]. [diunduh $2014 \mathrm{Sep}$ 21]; 53(2):298-307. Tersedia pada: http://www.iasj.net/iasj?func=fulltext\&aId=52983.

Maritim AC, Sanders RA, Watkins JB III. 2003. Diabetes, oxidative stress, and antioxidants: a review. J Biochem Mol Toxicol. 17(1):4-38. doi:10.1002/jbt.10058.

Martin CA, Milinsk MC, Visentainer JV, Matsushita M, De-Souza ND. 2007. Trans fatty acidforming processes in foods: a review. An Acad Bras Cienc [Internet]. [diunduh $2014 \mathrm{Sep}$ 21]; 79:343-350. Tersedia pada: http://www.ncbi.nlm.nih.gov/pubmed/17625687.

McMichael MA. 2007. Oxidative stress, antioxidants, and assessment of oxidative stress in dogs and cats. J Am Vet Med Assoc [Internet]. [diunduh 2014 Sep 2]; 231(5):714-720. Tersedia pada: http://www.ncbi.nlm.nih.gov/pubmed/1776442.

Noeman SA, Hamooda HE, Baalash AA. 2011. Biochemical study of oxidative stress markers in the liver, kidney and heart of high fat diet induced obesity in rats. Diabetol Metabol Synd [Internet]. [diunduh 2014 Mar 23]; 3(17):1-8. Tersedia pada: http://www.dmsjournal.com/ content/3/1/17.

Norton ID, Apte MV, Lux O, Haber PS, Pirola RC, Wilson JS. 1998. Chronic ethanol administration causes oxidative stress in the rat pancreas. J Lab Clin Med [Internet]. [diunduh 2014 Sep 28]; 131(5):442-446. Tersedia pada: http://segsydney.com.au/wp-content/uploads/2010/06/ Ron-Pirola-Article-8.pdf.

Puligundla P, Variyar PS, Ko S. 2012. Emerging trends in modification of dietary oils and fats, and health implications - a review. Sains Malay [Internet]. [diunduh 2014 Sep 8]; 41(7):871877. Tersedia pada: http://www.ukm.my/jsm/pdf_files/SM-PDF-41-7-2012/09\%20 Pradeep.pdf.

Sahin K, Sahin N, Kucuk O, Hayirli A, Prasad AS. 2009. Role of dietary zinc in heat-stressed poultry: a review. Poult Scien. 88:2176-2183. doi: 10.3382/ps.2008-00560.

Sartika RAD. 2008. Pengaruh asam lemak jenuh, tidak jenuh, dan asam lemak trans terhadap 
kesehatan. J Kesehat Masyarak Nas. 2:154-160 dalam Odang AAS, Sirajuddin S, Syam A. 2013.Analisis kadarasam lemak trans dalam gorengan dan minyak bekas hasilpenggorengan makanan jajanan di lingkungan workshop Universitas Hasanuddin Makassar. Prog Studi Ilmu Gizi Fakul Kesehat Masyarak Univ Hasanud Makass [Internet]. [diunduh 2014 Agu 31]; Hal 1-11. Tersedia pada: http://repository.unhas.ac.id/handle/123456789/5520.

Semma M. 2002. Trans fatty acids: properties, benefits, and risks. J Health Scien [Internet]. [diunduh 2014 Sep 8]; 48(1):7-13. Tersedia pada: http://jhs.pharm.or.jp/data/48(1)/48_7.pdf.

Sengupta P. 2011. A scientific review of age determination for a laboratory rat: how old is it in comparison with human age?. Biomed Internat [Internet]. [diunduh 2014 Sep 8]; 2:81-89. Tersedia pada: http://www.bmijournal.org/index.php/bmi/article/view/75/70.

Singh HP, Batish DR, Kaur S, Arora K, Kohli RK. 2006. A-pinene inhibits growth and induces oxidative stress in roots. Ann Bot. 98(6):1261-1269. doi:10.1093/aob/mcl213.

Stachowska E, Jamiol D, Chlubek D. 2010. Trans fatty acid and their role in inflammation and cardiovascular disease. Annal Academ Med Stetinen [Internet]. [diunduh 2014 Sep 8]; 56(3):30-38. Tersedia pada: http://www.pum.edu.pl/_data/assets/file/0016/40309/5603_030-038.pdf.

Suresh DR, Kumaran S, Annam V, Hamsaveena. 2010. Age related changes in malondialdehyde: total antioxidant capacity ratio - a novel marker of oxidative stress. Int J Phar Bioscien [Internet]. [diunduh 2014 Sep 1]; 1(2):1-6. Tersedia pada: http://www.researchgate.net/ publication/264194832_AGE_RELATED_CHANGES_IN_MALONDIALDEHYDE_ TOTAL_ANTIOXIDANT_CAPACITY_RATIO_A_NOVEL_MARKER_OF_ OXIDATIVE_STRESS._1_www.ijpbs.net_Bio_chemistry.

Sureshkumar V, Sarathchandra G, Ramesh J. 2013. Veterinary pharmacovigilance evaluation on impact of enrofloxacin administration on antioxidant status in broiler chicken. Int J Curr Microbiol App Scien [Internet]. [diunduh 2014 Sep 21]; 2(5):335-341. Tersedia pada: http://www.ijcmas.com/Archives/vol-2-/Veerapandian\%20Sureshkumar,\%20et\%20al. pdf.

Tjahjono K, Santoso, Ngestiningsih D. 2013. Trans fatty acids increase nitric oxide levels and pancreatic beta-cell necrosis in rats. Univ Med [Internet]. [diunduh 2014 Sep 8]; 32(1):5159. Tersedia pada: http://www.researchgate.net/profile/Santoso_Jaeri/publication /259802545_Trans_fatty_acids_increase_nitric_oxide_levels_and_pancreatic_beta-cell_ necrosis_in_rats/links/0046352dfeaa25318b000000.

Tuminah S. 2009. Efek asam lemak jenuh dan asam lemak tak jenuh trans terhadap kesehatan. Media Penelit dan Pengembang Kesehat. 19 Supl 2:S13-S20.

Verlaan M, Roelofs HMJ, van Schaik A, Wanten GJA, Jansen JBMJ, Peters WHM, Drenth JPH. 2006. Assessment of oxidative stress in chronic pancreatitis patients. World J Gastroenterol [Internet]. [diunduh 2014 Sep 8]; 12(35):5705-5710. Tersedia pada: http://www.wjgnet. com/1007-9327/12/5705.asp.

Yalçınkaya-Demirsöz S, Depboylu B, Doğru-Abbasoğlu S, Ünlüçerçi Y, Uysal M. 2009. Effects of high methionine diet on oxidative stress in serum, apo-B containing lipoproteins, heart, and aorta in rabbits. Ann Clinic Laborat Scien [Internet]. [diunduh 2014 Sep 21]; 39(4):386- 
391. Tersedia pada: http://www.annclinlabsci.org/content/39/4/386.full.

Yan-Hong Z, Jie-Ping Y, Yi-Feng L, Xiao-Jun T, Mei M, Peng L, Ping A, Shi-Quan L, HongGang Y. 2006. Effects of Ginkgo biloba extract on inflammatory mediators (SOD, MDA, TNF- $\alpha$, NF- $\kappa B p 65$, IL-6) in TNBS-induced colitis in rats. Mediat Inflammat. 92642:1-6. doi:10.1155/MI/2006/92642.

Zafir A, Banu N. 2009. Induction of oxidative stress by restraint stress and corticosterone treatments in rats. Ind J Biochem Biophys [Internet]. [diunduh 2014 Sep 21]; 46:53-58. Tersedia pada: http://nopr.niscair.res.in/bitstream/123456789/3340/1/IJBB\%2046(1) \%2053-58.pdf. 